\title{
Biosorption of 2,4,6-trichlorophenol from Aqueous Medium Using Agro-waste: Pine (Pinus densiflora Sieb) Bark Powder
}

\author{
Nadavala Siva Kumar, ${ }^{\star}$ Mohammad Asif, Mansour I Al-Hazzaa \\ and Ahmed A. Ibrahim \\ Department of Chemical Engineering, College of Engineering, King Saud University, P.O. Box 800, \\ Riyadh 11421, Saudi Arabia \\ *Corresponding author: E-mail: shivanadavala@gmail.com, snadavala@ksu.edu.sa
}

Received: 01-10-2017

\begin{abstract}
Most industrial waste discharges are often contaminated with phenolic compounds, which constitute a major source of water pollution owing to their toxicity and low biodegradability. Development of cost-effective treatment of such industrial wastewater is therefore of paramount importance. Towards this end, we explore the efficacy of Pine bark powder (PBP), which is an agricultural solid waste material, as a low-cost biosorbent without any pre-treatment, for the adsorptive removal of 2,4,6-trichlorophenol (2,4,6-TCP) from aqueous media. The PBP was thoroughly characterized and the effect of important adsorption parameters were examined in the present investigation. The batch equilibrium data were analyzed using well-known isotherm models. Freundlich isotherm model provided the best description of the equilibrium biosorption behavior. At $25 \pm 1{ }^{\circ} \mathrm{C}$, the maximum biosorption capacity $\left(q_{\max }\right)$ was $289.09 \mathrm{mg} / \mathrm{g}$, which is higher than most biosorbents reported in the literature while the removal as high as $97 \%$ was obtained. Moreover, the biosorption process was fast, attaining equilibrium in less than $120 \mathrm{~min}$ of contact. The Elovich model accurately described the kinetics data. In view of high biosorption capacity and fast removal rates, PBP can be used for an efficient and cost-effective treatment of 2,4,6-TCP contaminated wastewater.
\end{abstract}

Keywords: Biosorption, Pine bark powder, 2,4,6-trichlorophenol, Kinetics and Isotherm models

\section{Introduction}

Water pollution is a major global environmental concern that requires immediate attention and sustainable solutions. Its main sources are untreated industrial effluents that release wastewater contaminated with VOCs, metal ions, and phenolic compounds into the environment. ${ }^{1}$ Among these pollutants, phenolic derivative 2,4,6-Trichlorophenol (TCP), is a known toxin owing to its positioning of the chlorine atoms (at position 2, 4 and 6) in the phenol ring. ${ }^{2}$ Often, industrial waste-water from paints, pharmaceuticals, pesticides, wood, pulp and paper industries are heavily contaminated with chlorophenols, ${ }^{3,4}$ which require pre -treatment before discharging into the environment. However, the structural stability and persistence of 2,4,6-TCP makes its removal quite challenging. ${ }^{5}$ The position of chlorine atoms relative to the hydroxyl group and the stable carbon-chlorine bond and are responsible for its toxicity. Exposure of humans to 2,4,6-TCP via inhalation leads to respiratory problems, altered pulmonary function and pulmonary lesions. Besides, even low concentrations (0.1 $\mathrm{mg} / \mathrm{L}$ ) of chlorophenols give undesirable palatability to the potable water. ${ }^{6}$ Both IARC (International Agency for Research on Cancer) and United States Environmental Protection Agency (USEPA, 1999) classify 2,4,6-TCP as a probable carcinogen to humans under group B2.?

For the removal of 2,4,6-TCP from the waste-water, several techniques, e.g. chemical-biological oxidation, microbial degradation, photocatalytic, ion exchange resins, catalytic oxidation processes have been suggested in the literature. ${ }^{8-11}$ However, most separation techniques are often expensive, necessitating the development of alternative treatment technology that is both efficient and affordable. Biosorption is a cost-effective, efficient, and environmentally friendly technique that is fast emerging as an alternative to conventional separation techniques. ${ }^{12}$ This led to the investigation of sorption capacities of lignocellulosic 
residues and agricultural wastes, which are abundantly available and do not require regeneration due to their low cost. ${ }^{13-26}$ Owing to abundance and ease of availability, Pine bark can prove to be a cost-effective alternative to other adsorbents used for wastewater treatment. In fact, the Pine bark was found to be effective in the removal of phenolic compounds (Phenol, 2-Chlorophenol and 4-Chlorophenol). ${ }^{27}$ Pine (Pinus densiflora) belongs to the family pinaceae, and is commonly found around the world.

In the current study, we have investigated the efficacy of the low-cost PBP adsorbent for the treatment of wastewater contaminated with 2,4,6-TCP. In the following, we first describe the synthesis of the PBP, followed by its rigorous characterization using BET surface area, FTIR spectroscopy, XRD, SEM, and elemental analysis to determine the carbon, hydrogen, and nitrogen $(\mathrm{CHN})$ and the presence of various functional groups. The effect important adsorption parameters, such as the solution $\mathrm{pH}$, biosorbent dosage, initial adsorbate concentrations and the contact time are examined on the uptake efficiency of the PBP. Both experimental kinetic and equilibrium data were processed with the help of well-known theoretical models. Finally, the removal efficacy of the present biosorbent is compared with other adsorbents reported in the literature.

\section{Materials and Methods}

\section{1. Materials}

Chemicals and other materials were obtained from Aldrich (St. Louis, USA). These chemicals were not purified prior to use. The chemical formula of 2,4,6-TCP is $\mathrm{C}_{6} \mathrm{H}_{3} \mathrm{Cl}_{3} \mathrm{O}$. Its molecular weight is $197.46 \mathrm{~g} / \mathrm{moL} .1 .0 \mathrm{~g}$ of $2,4,6-\mathrm{TCP}$ was dissolved in 1 litre of double distilled water to prepare the stock solution, which was used to prepare different solutions in the concentration range of $100-400 \mathrm{mg} / \mathrm{L}$. We adjusted the solution $\mathrm{pH}$ by adding $0.1 \mathrm{M} \mathrm{NaOH}$ and $0.1 \mathrm{M} \mathrm{HCl}$ solutions.

\section{2. Preparation of Pine Bark Powder Biosorbent}

The first step consisted of removing the dust and dirt particles from the pine tree bark by washing with distilled water. It was then dried at $60^{\circ} \mathrm{C}$ for $48 \mathrm{~h}$. Next, it was ground using a laboratory mill and sieved to obtain powder with narrow particle size distribution, which varied from 55 to $75 \mu \mathrm{m}$. In order to remove the lignin content of the powdered sample, it was soaked in $0.1 \mathrm{M} \mathrm{NaOH}$ followed by $0.1 \mathrm{M} \mathrm{H}_{2} \mathrm{SO}_{4}$. It was again washed using distilled water then oven dried at $70^{\circ} \sim$ $80^{\circ} \mathrm{C}$ for $6 \sim 9 \mathrm{~h}$ followed by cooling at ambient conditions. This final product was named 'PBP' (Pine bark powder).

\section{3. Batch Adsorption Studies}

Biosorption experiments were conducted using 125 $\mathrm{mL}$ conical flasks containing $0.1 \mathrm{~g}$ of the biosorbent and
$100 \mathrm{~mL}$ 2,4,6-TCP solutions with initial concentrations varying from 100 to $400 \mathrm{mg} / \mathrm{L}$. The samples were stirred on a shaking water bath temperature controller $\left(25 \pm 1{ }^{\circ} \mathrm{C}\right.$ at $220 \mathrm{rpm}$ ) till equilibrium was attained. The $\mathrm{pH}$ was varied from 2.0-10.0 in the present study. The slurry was filtered using ashless Whatman No.50 filter paper $(2.7 \mu \mathrm{m}$ size particle retention) to obtain the supernatant solution. UVVis spectrophotometer (Shimadzu UV-1601 Spectrophotometer, Japan) was used to determine the concentrations of 2,4,6-TCP in the supernatant solutions at the wavelength of $296 \mathrm{~nm}$. The amount of 2,4,6-TCP sorbed onto the PBP, $q_{e}(\mathrm{mg} / \mathrm{g})$, was computed using the following material balance relationship,

$$
q_{e}=\frac{\left(C_{0}-C_{e}\right) V}{W}
$$

where, $C_{\mathrm{e}}$ and $C_{0}$ are equilibrium and initial concentrations of 2,4,6-TCP in the solution $(\mathrm{mg} / \mathrm{L})$, respectively. $\mathrm{W}$ is the PBP mass in $\mathrm{mg}$ and $\mathrm{V}$ is the solution volume in L. During the batch kinetics studies, the 2,4,6-TCP uptake at a given time $t, q_{t}(\mathrm{mg} / \mathrm{g})$, was computed using,

$$
q_{t}=\mathrm{V}\left(C_{0}-C_{t}\right) / W
$$

where $C_{t}(\mathrm{mg} / \mathrm{L})$ is the concentration of the adsorbate at time, $t$ (min). The 2,4,6-TCP removal was computed by,

$$
\text { Removal }(\%)=\frac{\left(C_{0}-C_{e}\right)}{C_{0}} \times 100
$$

\section{Results and Discussion}

\section{1. Characterization of PBP}

The adsorbent was characterized to determine ash content, $\mathrm{CHN}$, moisture content, surface properties, and bulk density. These results are shown in Table 1.

Table 1. Elemental analysis, physical and surface characterization of PBP

\begin{tabular}{lc}
\hline Parameter & Value \\
\hline Odor & None \\
Color & Light Brownish \\
Moisture content $(\%)$ & 5 \\
Apparent (bulk) density $\left(\mathrm{g} / \mathrm{cm}^{3}\right)$ & 0.318 \\
Weight loss $(\%)$ & 42.6 \\
Ash content $(\%)$ & 5.62 \\
Multi point BET surface area $\left(\mathrm{m}^{2} / \mathrm{g}\right)$ & 1.410 \\
BET surface area $\left(\mathrm{m}^{2} / \mathrm{g}\right)$ & 0.104 \\
Pore radius $\left(\mathrm{A}^{0}\right)$ & 22.35 \\
Carbon $(\%)$ & 76.41 \\
Hydrogen $(\%)$ & 5.35 \\
Nitrogen $(\%)$ & 6.78 \\
\hline
\end{tabular}




\section{1. 1. FTIR Spectral Analysis}

The presence of various functional groups involved in 2,4,6-TCP biosorption were determined using FTIR. Fig. 1(a) and 1(b) shows the FTIR spectral data of the virgin PBP and 2,4,6-TCP loaded PBP in the range of 4000$400 \mathrm{~cm}^{-1}$. The main broad band peaks observed at $3377 \&$ $3420 \mathrm{~cm}^{-1}$ was assigned to the overlap of $-\mathrm{OH}$ stretching vibrations arising from hydroxyl groups and $-\mathrm{NH}$ stretching vibration mode of the amine functional groups. The strong absorption band observed at around $2918 \mathrm{~cm}^{-1}$ can be attributed to the $\mathrm{C}-\mathrm{H}$ stretching vibrations of $-\mathrm{CH}_{3}$ and $-\mathrm{CH}_{2}$ functional groups. The peak at $1618 \mathrm{~cm}^{-1}$ indicate the functional group region of $\mathrm{C}=\mathrm{O}, \mathrm{O}-\mathrm{H}$, and $\mathrm{C}-\mathrm{O}$ groups. The peak at $1518 \mathrm{~cm}^{-1}$ is assigned to a conjugated hydrogen bonded carbonyl group. The presence of car-

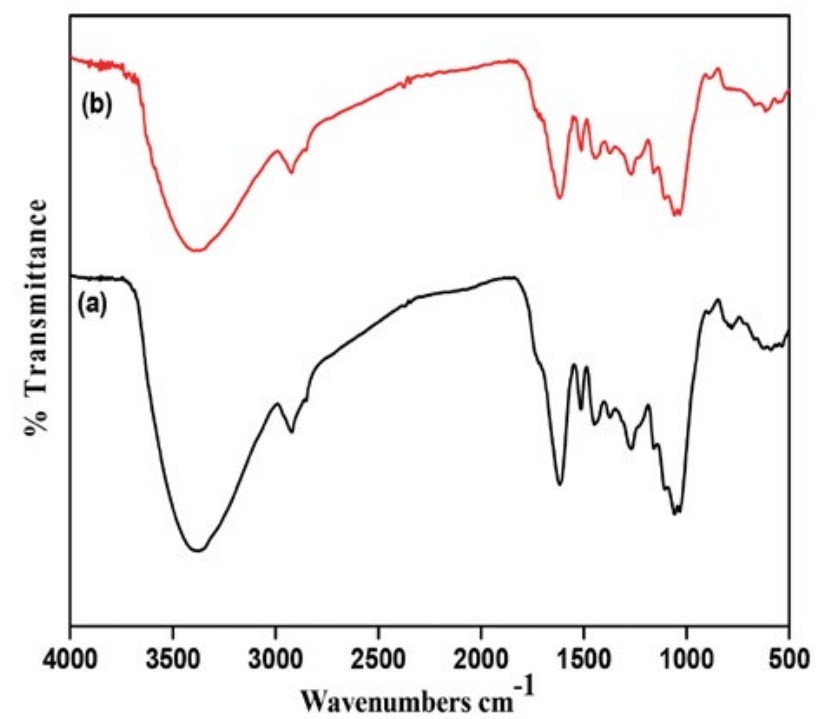

Figure 1. FTIR spectrum of (a) virgin PBP and (b) 2,4,6-trichlorophenol loaded PBP.

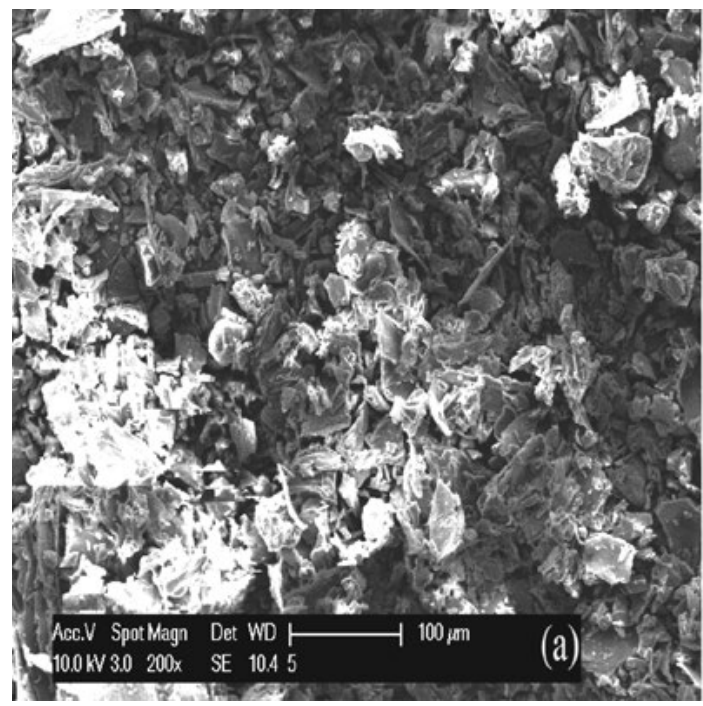

boxyl groups $(-\mathrm{COOH})$ is evident from the peak at 1440 $\mathrm{cm}^{-1}$. The peaks at 1059 and $617 \mathrm{~cm}^{-1}$ indicate the presence of alkyl halide (C-N and $\mathrm{C}-\mathrm{Cl}$ stretch). Fig. 1(a) and (b) show some peaks slightly shifted and/or broadened, in wavenumbers from 2913 to $2918 \mathrm{~cm}^{-1}, 1618$ to $1621 \mathrm{~cm}^{-1}$, 1518 to $1510 \mathrm{~cm}^{-1}, 1440$ to $1432 \mathrm{~cm}^{-1}, 1059$ to $1063 \mathrm{~cm}^{-1}$, 878 to $882 \mathrm{~cm}^{-1}, 767$ to $784 \mathrm{~cm}^{-1}, 612$ to $617 \mathrm{~cm}^{-1}$ were noticed in the spectra of virgin PBP and 2,4,6-TCP loaded PBP. The functional group(s) involvement is quite prominent as confirmed by the changes observed in FTIR spectrum. The FTIR spectral results further confirmed the fact that PBP is mainly made up of cellulose and lignin, containing functional groups such as hydroxyl, amino and carboxylic groups.

\section{1. 2. Scanning Electron Microscope (SEM) \& XRD Analysis}

SEM pictures (at different magnifications) revealed dense flaky independent plate like structures with typical agglomeration followed by consistent irregular surface morphology (Fig. 2a, b). The surface of PBP exhibits irregular structure typical of highly porous materials, confirming the possibility of 2,4,6-TCP getting adsorbed on the various parts of the biosorbent (Fig. 2b). X-Ray diffractogram of virgin PBR exhibited broad crested peaks (at $2 \theta=$ $29.8^{\circ}$ indicating amorphous nature of PBP (figure not shown).

\section{2. Effect of $\mathbf{p H}$}

It is a critical parameter that affects the process of the adsorption by influencing the interaction between the adsorbate and the adsorbent. The determination of the optimum $\mathrm{pH}$ is therefore vital for the efficient implementation of the adsorption based separation technology. ${ }^{28} \mathrm{The} \mathrm{pH}$ was varied from 2.0 to 10.0 in order to examine its effect

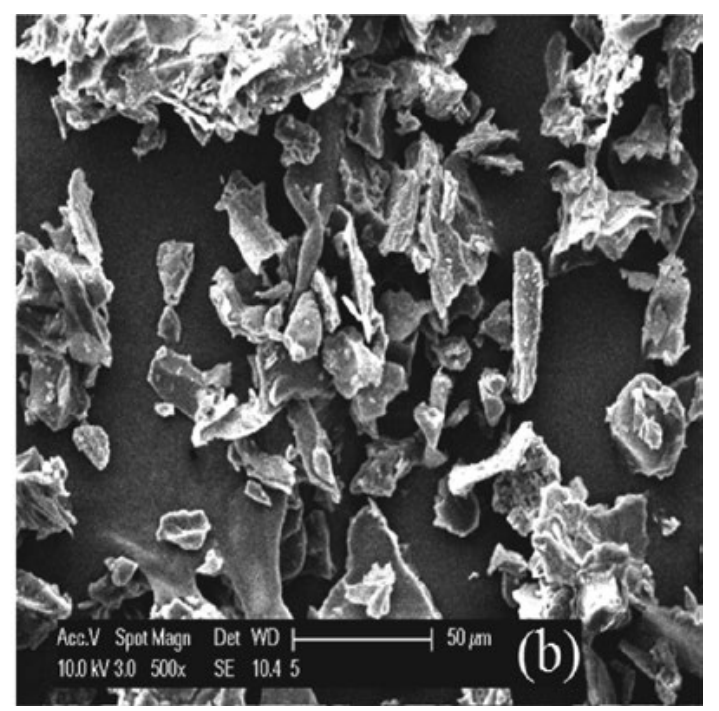

Figure 2. SEM micrographs of PBP at (a) 200x and (b) 500x magnification. 


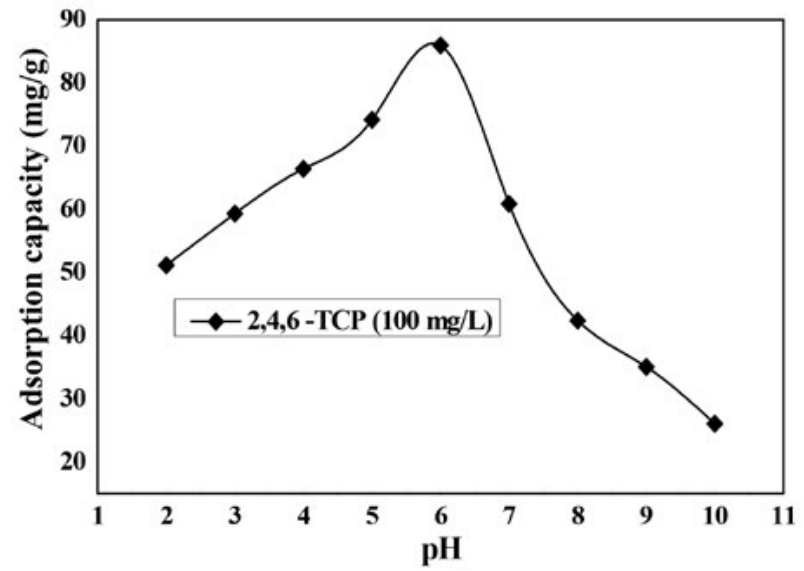

Figure 3. Influence of $\mathrm{pH}$ on the 2,4,6-trichlorophenol biosorption onto PBP. Experimental conditions: Temp $=25 \pm 1{ }^{\circ} \mathrm{C}$, adsorbent mass $=0.1 \mathrm{~g}$, initial concentrations $=100 \mathrm{mg} / \mathrm{L}$, agitation rate $=220$ rpm, contact time $=2 \mathrm{~h}$.

on the uptake capacity of the PBP. There is a strong correlation between the solution $\mathrm{pH}$ and the uptake of the chlorophenol as seen in Fig. 3. The profile shows a global maximum at $\mathrm{pH}$. The 2,4,6-TCP is in fact a weak acid having $\mathrm{pK}_{\mathrm{a}}$ value of 6.23 . Thus, the acidic $\mathrm{pH}$ below the $\mathrm{pKa}$ value favours 2,4,6-TCP to remain un-dissociated, and the dispersion interaction predominate. ${ }^{6}$ When the $\mathrm{pH}$ value is greater than 6 , the biosorption capacity decreases as a result of electrostatic repulsion between the surface site and the negatively charged chlorophenolate anion or due to the chlorophenolate-chlorophenolate anions interaction in the solution. ${ }^{29}$ At low $\mathrm{pH}$, the protonated chlorophenols were more amenable to adsorption as compared to their ionized forms. A similar analogy was attributed to the 2,4,6-TCP adsorption on other adsorbents, such as PU@PDA@MSNs sponge, ${ }^{30}$ Acacia leucocephala bark, ${ }^{19}$ urea-formaldehyde macroporous foams (UFMF), ${ }^{31}$ coconut shell-based activated carbons, ${ }^{32}$ oil palm empty fruit bunch-based activated carbons and coconut husk-based activated carbon. ${ }^{33,34}$ Therefore, the optimal $\mathrm{pH}$ of 6 was fixed in in the present study.

\section{3. Influence of Biosorbent Dosage}

This is a key parameter that affects the cost-effectiveness of the adsorption technology. The amount of PBP was varied from 0.05 to $0.8 \mathrm{~g}$ in the test solution $\left(C_{0}=100\right.$ $\mathrm{mg} / \mathrm{L}$ ) to examine its effect on the removal efficacy the 2,4,6-TCP. Since the equilibrium was attained in $2 \mathrm{~h}$, the total contact time was kept $3 \mathrm{~h}$ in all experiments. It is clear from Fig. 4 that the \% removal of chlorophenol increases with the increase in the amount of the biosorbent, reaching as high as $97 \%$, when $0.4 \mathrm{~g}$ of the biosorbent was used. This can be attributed to greater availability of the solute molecules per unit mass of the sorbent (i.e., higher solute/adsorbent ratio) resulting in greater removal till saturation conditions are reached. Further increase in the

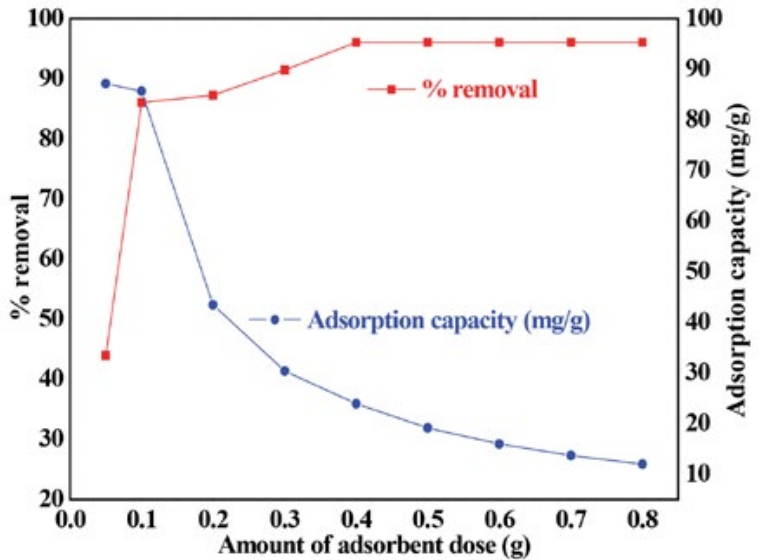

Figure 4. Influence of adsorbent dosage on the 2,4,6- trichlorophenol biosorption onto PBP [Removal (\%) and biosorption capacity (mg/g)]. Experimental conditions: Temp $=25 \pm 1^{\circ} \mathrm{C}$ biosorbent dosage $=0.05-$ $0.8 \mathrm{~g}$, initial concentrations $=100 \mathrm{mg} / \mathrm{L}, \mathrm{pH} 6.0$, contact time $2 \mathrm{~h}$.

amount of PBP however failed to improve the removal efficiency, because increasing the amount of PBP resulted in reduced equilibrium loading capacities, $\mathrm{q}_{\mathrm{e}}(\mathrm{mg} / \mathrm{g})$, which is in fact the amount of the adsorbate removed per unit mass of biosorbent.

\section{4. Effect of the Initial Concentration and the Contact Time}

An important aspect of the efficient and cost-effective implementation of the wastewater treatment process is the equilibrium contact time. Shorter equilibrium contact time enhances the efficiency of the separation process. Fig. 5 shows the progress of the biosorption with time for different strength of 2,4,6-TCP solution. The uptake of 2,4,6TCP $(\mathrm{mg} / \mathrm{g})$ increases with the increase in contact time. The uptake rate is initially faster, but tend to gradually decrease with time as the vacant sites available on the biosorbent surface is gradually occupied by the adsorbate. It took $120 \mathrm{~min}$ for the equilibrium to be established. Therefore, the $120 \mathrm{~min}$ of contact was fixed for the rest of the batch experiments.

For the adsorptive removal of 2,4,6-TCP, a wide range of adsorption rates has been reported in the literature. Using ash derived from wheat (Triticum aestivum L.) straw, Chen et al. reported equilibrium contact time of 7 days, which consisted of initial 3 days of rapid adsorption. ${ }^{35}$ Using calcined $\mathrm{Mg} / \mathrm{Al}-\mathrm{CO}_{3}$ layered double hydroxide $(\mathrm{CLDH})$ obtained equilibrium adsorption time of $180 \mathrm{~min}$ for $C_{0}=25-400 \mathrm{mg} / \mathrm{L} .{ }^{36}$ Denizli et al. also reported $240 \mathrm{~min}$ of equilibrium contact time for $C_{0}=500 \mathrm{mg} / \mathrm{L} \cdot{ }^{37} \mathrm{In}$ another study, $400 \mathrm{~min}$ was required for the removal of 2,4,6-TCP using PU@PDA@MSNs sponge for small initial concentrations $(50-100 \mathrm{mg} / \mathrm{L}){ }^{30}$ Radhika et al. found that the equilibrium time was 60-210 min using coconut shell-based commercial grade activated carbon for the initial concentration of $10-100 \mathrm{mg} / \mathrm{L} .{ }^{32}$ Siva Kumar et al. found that the 


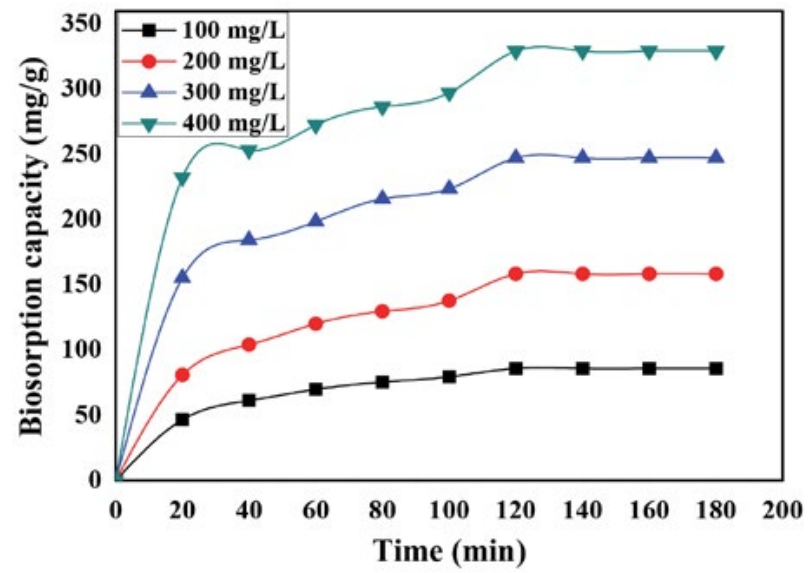

Figure 5. Influence of contact time on the biosorption of the 2,4,6-trichlorophenol for different initial concentrations. (- $\mathrm{C}_{0}=$ $100 \mathrm{mg} / \mathrm{L},(\bullet) \mathrm{C}_{0}=200 \mathrm{mg} / \mathrm{L},(\boldsymbol{\Delta}) \mathrm{C}_{0}=300 \mathrm{mg} / \mathrm{L},(\boldsymbol{\nabla}) \mathrm{C}_{0}=400$ $\mathrm{mg} / \mathrm{L}$. [Experimental conditions: Temp $=25 \pm 1{ }^{\circ} \mathrm{C}$, biosorbent dosage $=0.1 \mathrm{~g}, \mathrm{pH}=6.0$, contact time $3 \mathrm{~h}$, agitation rate: $220 \mathrm{rpm}]$.

equilibrium time for the 2,4,6-TCP biosorption on Acacia leucocephala bark was $180 \mathrm{~min}$ for $C_{0}=50-200 \mathrm{mg} / \mathrm{L}^{20}$

\section{5. Biosorption Kinetics}

Adsorption kinetics critically affects the performance of an adsorbent. This aspect was therefore investigated for different initial 2,4,6-TCP concentrations in the present study. The experimental data were analyzed using Pseudo-first-order, pseudo-second-order, Elovich model and intra-particle diffusion kinetic models, which are listed in the following. The pseudo-first-order kinetic model is usually represented as: ${ }^{38}$

$$
\log \left(q_{e}-q_{t}\right)=\log q_{e}-\frac{k_{1} t}{2.303}
$$

where $k_{1}\left(\mathrm{~min}^{-1}\right)$ is the first order rate constant, which can be evaluated from the slope of the $\log \left(q_{e}, q_{t}\right)$ versus $t$ (figure not shown). Table 2 lists $k_{1}$ values for $C_{0}=100-400$ $\mathrm{mg} / \mathrm{L}$ along with correlation coefficients $\left(\mathrm{R}^{2}\right)$, which is a statistical measure of the goodness of fit. The actual experimental $q_{e}$ values are also presented in the table. There is a substantial difference between predicted and experimental values of $q_{e}$, which tends to increase with the increase in the solution concentration. For low initial concentrations, the difference is almost $30 \%$, which increase several folds at higher solution concentrations. Clearly, the first order kinetics fails to provide an adequate description of the biosorption of 2,4,6-TCP onto PBP.

The pseudo-second-order kinetic model is generally represented as: ${ }^{39}$

$$
\frac{t}{q_{t}}=\frac{1}{k_{2} q_{e}^{2}}+\left(\frac{1}{q_{e}}\right) t
$$

The plot of $t / q_{t}$ versus $t$ (figure not shown) in the above equation yields the $q_{e}$ as the slope and $k_{2}$ as the intercept. These values are listed in Table 2 along with corresponding values of $\mathrm{R}^{2}$. The agreement between predicted and experimental values of $q_{e}$ is excellent. The difference between the two is low for $C_{0}=100 \mathrm{mg} / \mathrm{L}$, which unlike the first order kinetic fit, tends to decrease as $C_{0}$ increases. For the highest solution concentration considered here, the difference is hardly $2.5 \%$. This confirms the superiority of the pseudo-second-order kinetics as compare to the first-order kinetics.

The biosorption kinetics of 2,4,6-TCP onto PBP was also examined using Elovich equation: ${ }^{40}$

$$
q_{t}=\left(\frac{1}{b}\right) \ln (a b)+\frac{1}{b} \ln t
$$

where $a(\mathrm{mg} / \mathrm{g} / \mathrm{min})$ is the initial biosorption rate and $b(\mathrm{~g} /$ $\mathrm{mg}$ ) is the desorption constant related to the chemisorption activation energy and the extent of the surface coverage of the adsorbent. The plot of $\ln t$ versus $\mathrm{q}_{t}$ yields parameters $(1 / b)$ and $(1 / b) \ln (a b)$ as its slope and the intercept, respectively. From the Table 2, it can be seen that the computed $q_{e}$ values from Elovich model show good agreement with experimental data.

\section{6. Intraparticle Diffusion Model}

The transport of the solute molecules from the bulk liquid to the interiors of the porous structures of the adsorbent involves two mass transport resistances. One is due to the film or the boundary layer surrounding the adsorbent. The greater the thickness of this layer, the higher will be the resistance to the mass transport. Another resistance to the mass transport is due to the movement of the external species inside the pores of the adsorbent, which is also often termed as the intraparticle diffusion. In the literature, the dependence of the concentration of the adsorbate on the time is mathematically expressed as: ${ }^{41}$

$$
q_{t}=k_{i d} t^{1 / 2}+C
$$

where $k_{i d}\left(\mathrm{mg} / \mathrm{g} \cdot \mathrm{min}^{1 / 2}\right)$ is the slope of the square root of time versus $q_{t}$ plot while $\mathrm{C}$ is the intercept, which is a measure of the boundary layer thickness (figure not shown). The computed $k_{i d}$ values are shown in Table 2. If equation (7) yields a linear trend passing through the origin, then the intraparticle diffusion is the lone rate limiting step. From the table, it is clear that the intercept $\mathrm{C}$ is not zero. Therefore, the presence of other mass transport mechani$\mathrm{sm}$, besides the intraparticle diffusion, cannot be ruled out in the biosorption of 2,4,6-TCP.

Figure 6a-d shows the comparison of the experimental data and model predictions for the 2,4,6-TCP concentrations ranging from $100-400 \mathrm{mg} / \mathrm{L}$. The pseudo-first order, pseudo-second order, intraparticle diffusion and Elo- 

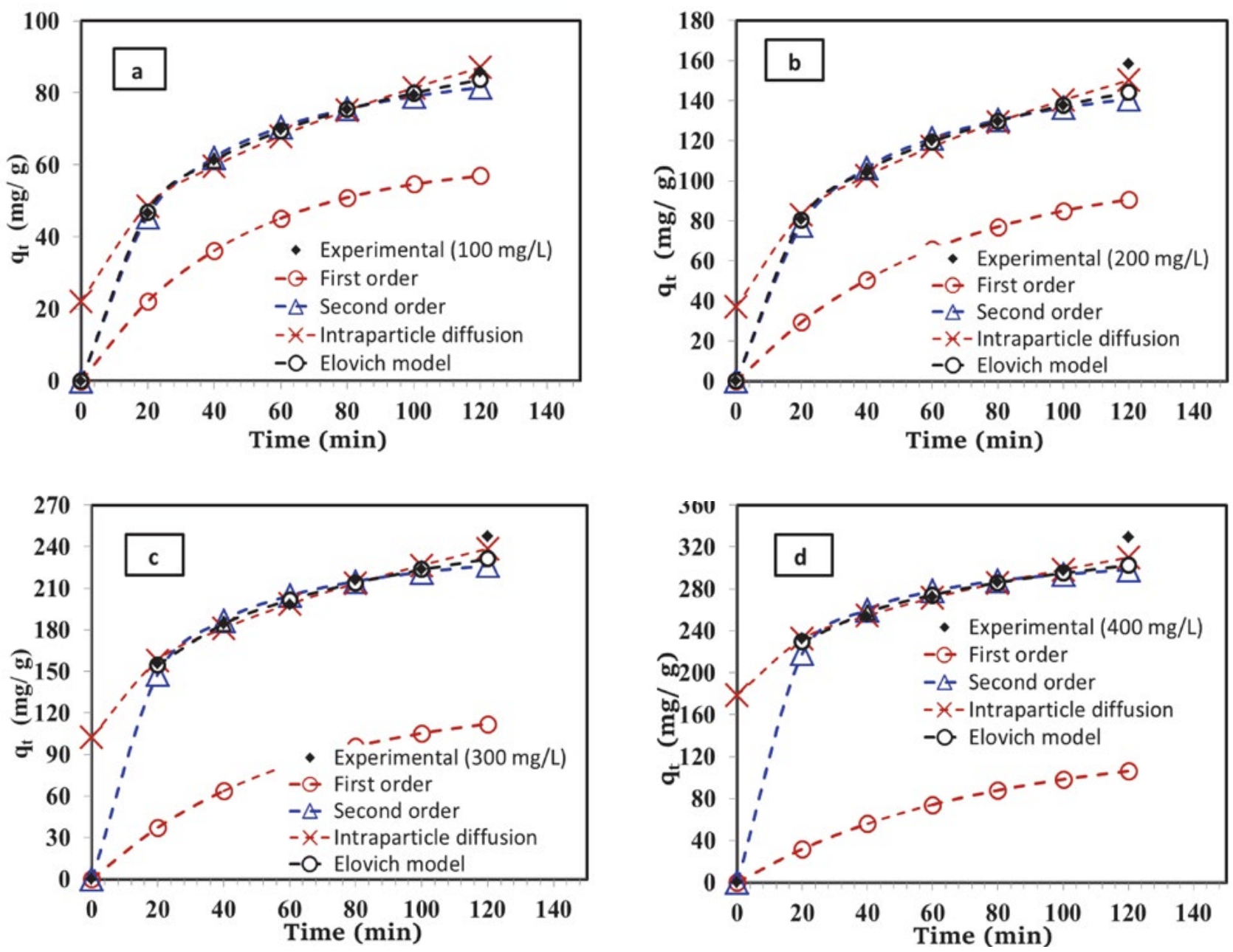

Figure 6. Comparison of experimental and calculated values obtained from the pseudo-first order, pseudo-second order, intraparticle diffusion and Elovich kinetic models (a-d).

vich kinetic equations are considered in the comparison. It is clear from the figures that the predictions of the Elovich kinetic model show an excellent agreement with the experimental data.

\section{7. Validity of Kinetic Models}

The validity of three kinetic models in accurately describing the biosorption process was carried out by computing the normalized standard deviation $\Delta q_{t}(\%)$. It is defined as:

$$
\Delta q_{t}(\%)=100 \times \sqrt{\sum_{i=1}^{N} \frac{\left[\left(q_{t, \text { exp }}-q_{t_{t, \text { exi }}}\right) / q_{t_{i}, \exp }\right]^{2}}{(N-1)}}
$$

where 'exp', 'cal' and ' $\mathrm{N}$ ' denote experimental, calculated values and the number of data points, respectively. Lower values of normalized standard deviation $\Delta q_{t}(\%)$ indicate better data fit. The computed parameters of the models, their corresponding correlation coefficients $\left(\mathrm{R}^{2}\right)$, and $\Delta q_{t}$
(\%) values are listed in Table 2. The pseudo-first-order kinetic model gives $\Delta q_{t}(\%)$ as high as $83 \%$ while the pseudosecond order and Elovich models give $\Delta q_{t}(\%)$ values ranging from $1.4-3.5 \%$ and $0.50-1.2 \%$, respectively. Based on the correlation coefficients $\left(\mathrm{R}^{2}\right)$ and normalized standard deviation $\Delta q_{t}(\%)$ values, the $2,4,6-\mathrm{TCP}$ adsorption on PBP is best described by the Elovich model model.

\section{8. Biosorption Isotherm Models}

In order to mathematically describe the equilibrium distribution of the adsorbate in the liquid solution and the adsorbent, adsorption isotherm models are used. These models accounts for the type of coverage, the nature of the interaction between the adsorbate and the adsorbent surface, and its homogeneity/heterogeneity. In the present study, we focus our attention on three different isotherms models, i.e. Langmuir, Freundlich and Dubinin-Radushkevich to analyze the equilibrium experimental data.

The generalized form of Langmuir isotherm is represented by: ${ }^{42}$ 
Table 2. Kinetic parameters biosorption of 2,4,6-TCP on PBP

\begin{tabular}{|c|c|c|c|c|}
\hline \multirow[t]{2}{*}{ Parameter } & \multicolumn{4}{|c|}{ Initial concentration of $2,4,6$-trichlorophenol $(\mathrm{mg} / \mathrm{L})$} \\
\hline & 100 & 200 & 300 & 400 \\
\hline \multirow[t]{2}{*}{$\mathrm{q}_{(\mathrm{e}, \exp )}(\mathrm{mg} / \mathrm{g})$} & 85.90 & 158.47 & 247.20 & 329.21 \\
\hline & \multicolumn{3}{|c|}{ Pseudo-first-order-kinetic model } & \\
\hline $\mathrm{q}_{(\mathrm{e}, \mathrm{cal})}(\mathrm{mg} / \mathrm{g})$ & 61.14 & 105.59 & 128.54 & 130.49 \\
\hline$k_{1}\left(\min ^{-1}\right)$ & 0.022 & 0.016 & 0.017 & 0.014 \\
\hline $\mathrm{R}^{2}$ & 0.979 & 0.974 & 0.994 & 0.999 \\
\hline \multirow[t]{2}{*}{$\Delta q_{t}(\%)$} & 44 & 54.31 & 69.59 & 83.80 \\
\hline & \multicolumn{3}{|c|}{ Pseudo-second-order-kinetic model } & \\
\hline $\mathrm{q}_{(\mathrm{e}, \text { cal })}(\mathrm{mg} / \mathrm{g})$ & 96.74 & 168.06 & 253.08 & 321.73 \\
\hline$k_{2}(\mathrm{~g} / \mathrm{mg} / \mathrm{min})$ & $4.6 \times 10^{-4}$ & $2.6 \times 10^{-4}$ & $2.8 \times 10^{-4}$ & $3.3 \times 10^{-4}$ \\
\hline $\mathrm{R}^{2}$ & 0.999 & 0.998 & 0.997 & 0.997 \\
\hline \multirow[t]{2}{*}{$\Delta q_{t}(\%)$} & 1.37 & 2.24 & 2.95 & 3.49 \\
\hline & \multicolumn{3}{|c|}{ Elovich model } & \\
\hline $\mathrm{q}_{(\mathrm{e}, \mathrm{cal})}(\mathrm{mg} / \mathrm{g})$ & 83.67 & 144.15 & 231.13 & 302.41 \\
\hline $1 / \mathrm{b}(\mathrm{mg} / \mathrm{g})$ & 20.49 & 35.57 & 42.64 & 40.72 \\
\hline $\mathrm{R}^{2}$ & 0.999 & 0.999 & 0.995 & 0.986 \\
\hline \multirow[t]{2}{*}{$\Delta q_{t}(\%)$} & 0.50 & 0.63 & 0.95 & 1.18 \\
\hline & \multicolumn{3}{|c|}{ Weber-Morris } & \\
\hline$k_{i d}$ & 5.92 & 10.32 & 12.41 & 11.96 \\
\hline $\mathrm{C}$ & 22.12 & 37.06 & 102.4 & 178.7 \\
\hline $\mathrm{R}^{2}$ & 0.979 & 0.987 & 0.989 & 0.998 \\
\hline$\Delta q_{t}(\%)$ & 3.06 & 2.36 & 1.51 & 0.38 \\
\hline
\end{tabular}

$$
\frac{1}{q_{e}}=\frac{1}{q_{m} K_{L} C_{e}}+\frac{1}{q_{m}}
$$

where $\mathrm{q}_{\mathrm{e}}(\mathrm{mg} / \mathrm{g})$ is the amount of the solute adsorbed per unit mass of adsorbent, $\mathrm{C}_{\mathrm{e}}(\mathrm{mg} / \mathrm{L})$ is its equilibrium concentration in solution, $\mathrm{q}_{\mathrm{m}}$ is the monolayer biosorption capacity of the adsorbent $(\mathrm{mg} / \mathrm{g})$ and $\mathrm{K}_{\mathrm{L}}(\mathrm{mg} / \mathrm{L})$ is the Langmuir equilibrium constant, respectively. The graph of $1 / \mathrm{q}_{\mathrm{e}}$ versus $1 / \mathrm{C}_{\mathrm{e}}$ has been plotted to determine both $\mathrm{q}_{\mathrm{m}}$ and $\mathrm{K}_{\mathrm{L}}$. The suitability of Langmuir type adsorption can be analysed using the following dimensionless parameter $\left(R_{L}\right):{ }^{43}$

$$
R_{L}=\frac{1}{1+K_{L} C_{0}}
$$

where $\mathrm{C}_{0}$ is the initial adsorbate concentration in solution $(\mathrm{mg} / \mathrm{L})$. For values of $\mathrm{R}_{\mathrm{L}}$ less than unity, the biosorption is favored. $\mathrm{R}_{\mathrm{L}}$ values greater than unity indicate that the biosorption process is unfavorable. In the current study, $\mathrm{R}_{\mathrm{L}}$ values were found varying from 0 to 1 , indicating that Langmuir adsorption is favorable.

Another widely used relationship, Freundlich isotherm model is given as: ${ }^{44}$

$$
q_{\mathrm{e}}=K_{F} C_{e}^{1 / n}
$$

where $K_{F}$ is a constant related to the adsorption capacity and $(1 / n)$ is related to the adsorption intensity. For a favourable sorption, $n>1$. Taking the log of both sides, the above equation can be linearized as follows:

$$
\ln q_{\mathrm{e}}=\ln K_{F}+\left(\frac{1}{n}\right) \ln C_{e}
$$

In order to gain a greater insight into the biosorption process, one can also use the Dubinin-Radushkevich isotherm model to fit the experimental data. The linearized form of this isotherm model can be mathematically expressed as: ${ }^{45}$

$$
\ln q_{e}=\ln q_{m}-B \varepsilon^{2}
$$

where $q_{m}(\mathrm{mg} / \mathrm{g})$ is the maximum adsorption capacity, $B$ is a the activity coefficient related to mean adsorption energy, and $\varepsilon$ is the Polanyi potential defined as :

$$
\varepsilon=R T \ln \left[\frac{1}{C_{e}}+1\right]
$$

where $R$ is the gas constant $(8.314 \mathrm{~J} / \mathrm{mol} \mathrm{K})$ and $T$ is the absolute temperature. The mean free energy ' $E$ ' of adsorption per molecule of the adsorbate is determined using the constant ' $B$ ' using the following relationship: 


$$
E=(2 B)^{-0.5}
$$

A plot of $\varepsilon^{2}$ versus $\ln \left(\mathrm{q}_{\mathrm{e}}\right)$ enables determination of constants $E$ and $q_{m}$. The nature of the biosorption process is characterized by the parameter E. Smaller values of $\mathrm{E}(<8 \mathrm{~kJ} /$ $\mathrm{mol}$ ) indicate that biosorption is purely physical. On the other hand, higher $\mathrm{E}$ values $(8<E<16 \mathrm{~kJ} / \mathrm{mol})$ indicate that the sorption process is chemical ion-exchange. We present the model parameters for all the three isotherms, i.e. Freundlich, Langmuir and Dubinin-Radushkevich in Table 3 for comparison along with values of the correlation coefficient $\left(\mathrm{R}^{2}\right)$. The predictions of all the isotherm models along with the experimental data are presented in Figure 7. Clearly, the Freundlich isotherm fits the experimental sorption data better than both Langmuir and Dubinin-Radushkevich models.

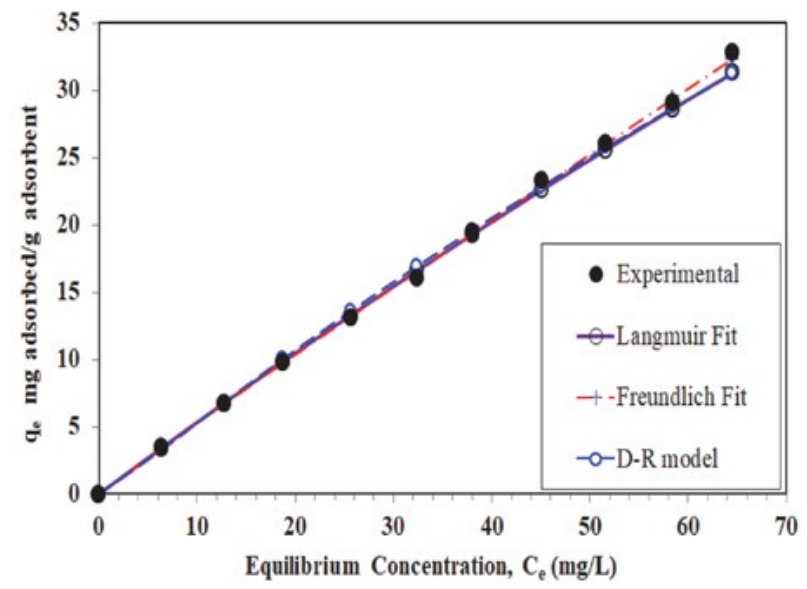

Figure 7. Comparison of experimental data with predictions of isotherm models.

\section{8. 1. Validity of Isotherm Models}

The capability of the present isotherm models in accurately describing the biosorption process was evaluated by computing the normalized standard deviation $\Delta q_{e}(\%)$ as follows:

$$
\Delta q_{e}(\%)=100 \times \sqrt{\frac{1}{(N-1)} \sum_{i=1}^{N}\left[\left(q_{e, i}-q_{\bmod , i}\right) / q_{e, i}\right]^{2}}
$$

where ' $\mathrm{q}_{\mathrm{e}^{\prime}, i}{ }^{\prime}, \mathrm{q}_{\text {mod' }}$ ' and ' $\mathrm{N}$ ' denote experimental, model values and the number of data points, respectively. In all cases, $\mathrm{R}^{2}$ values exceeded 0.997 and low $\Delta q_{e}(\%)$ were obtained in the present study (Table 3). It is however clear from the table that the Freundlich isotherm described the experimental data better than the other two models. This suggests that surface or pore heterogeneity plays a role in 2,4,6-TCP adsorption. The present results also agree with earlier works, which reported that the Freundlich model provided better representation of the 2,4,6TCP adsorption using oil palm empty fruit bunch and activated clay. ${ }^{4,33}$

\section{8. 2. Comparison of PBP with Other Adsorbents}

Fig. 8 compares the adsorption capacities of various adsorbents reported in the literature. Clearly, PBP is a better adsorbent for the removal of 2,4,6-Trichlorophenol as compared to other reported adsorbents. ${ }^{6,20,30-32,36,46-48 .}$ Its uptake capacity is found to be $289.09 \mathrm{mg} / \mathrm{g}$, which is higher than most other agro-waste based adsorbents. This clearly establishes the efficacy of the PBP for the cost-effective removal of 2,4,6-Trichlorophenol from an aqueous media.

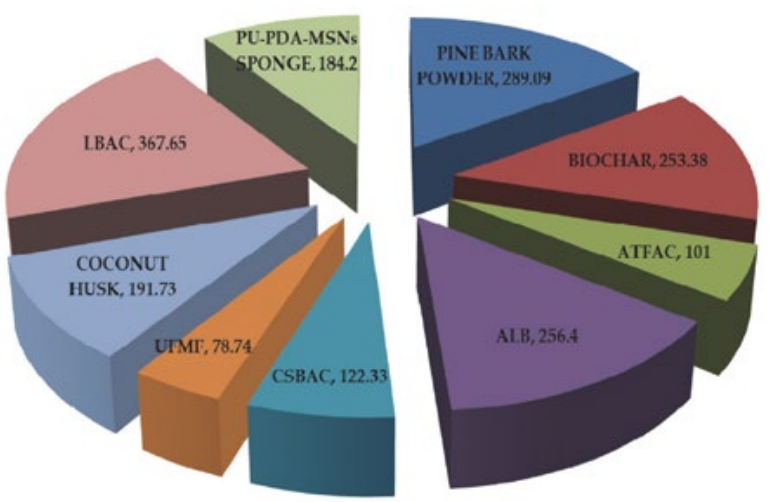

Figure 8. Comparison of maximum monolayer adsorption capacities of various Adsorbents for 2,4,6-TCP. [Acid treated coconut fiber activated carbon (ATFAC); Acacia leucocephala bark (ALB); Coconut shell-based activated carbon (CSBAC); Urea-formaldehyde macroporous foams (UFMF); Loosestrife-based activated carbon (LBAC).

\section{Conclusion}

In this study, the potential of PBP (agro-waste material) for the 2,4,6-TCP removal from wastewater over a

Table 3. Isotherm parameters for the biosorption of 2,4,6-TCP on PBP

\begin{tabular}{lcccc}
\hline Isotherms & Constants & & $\mathbf{R}^{2}$ & $\Delta \boldsymbol{q}_{e}(\%)$ \\
\hline Langmuir & $\mathrm{q}_{\mathrm{m}}(\mathrm{mg} / \mathrm{g})$ & $\mathrm{b}(\mathrm{L} / \mathrm{mg})$ & & \\
& 289.09 & 0.002 & 0.999 & 2.43 \\
Freundlich & $\mathrm{K}_{\mathrm{F}}\left((\mathrm{mg} / \mathrm{g})(\mathrm{L} / \mathrm{mg})^{1 / \mathrm{n}}\right)$ & $\mathrm{n}$ & & \\
& 0.565 & 1.030 & 0.999 & 1.48 \\
Dubinin-Radushkevich & $\mathrm{q}_{\mathrm{s}}(\mathrm{mmol} / \mathrm{g})$ & $\mathrm{E}(\mathrm{kJ} / \mathrm{mol})$ & & \\
& 4.84 & 7.60 & 0.997 & 3.51 \\
\hline
\end{tabular}


wide range of concentrations has been examined. The FTIR study confirms the presence of hydroxyl, amine and carboxyl functional groups on the surface of the adsorbent, while SEM study reveals irregular porous surface morphology. The biosorbent performed better under acidic conditions (optimal $\mathrm{pH}$ of 6). The biosorption process was fast since equilibrium was achieved within 120 minutes of contact. The sorption behaviour was accurately represented by the pseudo-second order kinetics as compared to other kinetic models. With an increase in the PBP dosage, the equilibrium adsorption capacity $(\mathrm{mg} / \mathrm{g})$ gradually decreased. On the other hand, the removal capacity as high as $97 \%$ was obtained for $0.4 \mathrm{~g} / \mathrm{L}$ of adsorbent. However, further increase in its dosage failed to improve the removal efficiency. Three different isotherm models (Langmuir, Freundlich and Dubinin-Radushkevich) were used to represent the experimental equilibrium data. The Langmuir isotherm model predicted the maximum biosorption capacity of $289.09 \mathrm{mg} / \mathrm{g}$ at $25 \pm 1{ }^{\circ} \mathrm{C}$. These findings conclude that PBP, owing to its ease of availability and environment friendly nature, can potentially replace existing sorbents for the removal of 2,4,6-TCP from aqueous media.

\section{Acknowledgments}

Authors appreciate the support of the Deanship of Scientific Research at the King Saud University for the Research Group RGP-1437-003.

\section{References}

1. S. K. Nadavala, K. Swayampakula, V. M. Boddu, K. Abburi, J. Hazard. Mater. 2009, 162, 482-489.

DOI:10.1016/j.jhazmat.2008.05.070

2. P. Podkoscielny, A. Dbrowski, O. V. Marijuk, Appl. Surf. Sci. 2003, 205, 297-303. DOI:10.1016/S0169-4332(02)01154-6

3. R. Gao, J. Wang, J. Hazard. Mater. 2007, 145, 398-403. DOI:10.1016/j.jhazmat.2006.11.036

4. B. H. Hameed, Colloid. Surface A. 2007, 307, 45-52. DOI:10.1016/j.colsurfa.2007.05.002

5. R. D. Vidic, M. T. Suidan, R. C. Brenner, Environ. Sci. Technol. 1993, 27, 2079-2085. DOI:10.1021/es00047a013

6. S. Mubarik, A. Saeed, M. M. Athar, M. Iqbal, J. Ind. Eng. Chem. 2016, 33, 115-121. DOI:10.1016/j.jiec.2015.09.029

7. Integrated Risk Information System (IRIS) on 2,4,6-Trichlorophenol. National Center for Environmental Assessment, Office of Research and Development, Washington, D. C.: USEPA, 1999.

8. M. Kurian, R. Babu, J. Environ. Chem. Eng. 2013, 1, 86-91. DOI:10.1016/j.jece.2013.04.005

9. K. A. McAllister, H. Lee, J. T. Trevors, Biodegradation. 1996, 7, 1-40. DOI:10.1007/BF00056556

10. C. G. Oh, J. H. Ahn, S. K. Ihm, Reac. Funct. Poly. 2003. 57,
103-111. DOI:10.1016/j.reactfunctpolym.2003.08.003

11. N. S. Kumar, M. V. Subbaiah, A. S. Reddy, A. Krishnaiah, J. Chem. Tech. Biotechnol. 2009, 84, 972-981.

DOI: $10.1002 /$ jctb. 2120

12. J. Febrianto, A. N. Kosasih, J. Sunarso, Y. H. Ju, N. Indraswati, S. Ismadji, J. Hazard. Mater. 2009. 162, 616-645.

DOI:10.1016/j.jhazmat.2008.06.042

13. H. Allaboun, F. Abu Al-Rub, Materials. 2016, 9, 251-265. DOI:10.3390/ma9040251

14. I. P. Bras, L. Santos, A. Alves, Env. Sci. Technol. 1999, 33, 631634. DOI:10.1021/es980402v

15. L. Dupont, J. Bouanda, J. Dumonceau, M. Aplincourt, J. Colloid Interf. Sci. 2003, 263, 35-41.

DOI:10.1016/S0021-9797(03)00241-8

16. V. K. Garg, R. Gupta, A. B. Yadav, R. Kumar, Bioresour. Technol. 2003, 89, 121-124.

DOI:10.1016/S0960-8524(03)00058-0

17. J. R. Rao, T. Viraraghavan, Bioresour. Technol. 2002, 85, 165171. DOI:10.1016/S0960-8524(02)00079-2

18. N. Ratola, C. Botelho, A. Alves, J. Chem. Tech. Biotechnol. 2003, 78, 347-351. DOI:10.1002/jctb.784

19. N. Siva Kumar, K. Min, J. Chil. Chem. Soc. 2011, 56, 539-545. DOI:10.4067/S0717-97072011000100004

20. N. Siva Kumar, H. S. Woo, K. Min, Colloid. Surface B. 2012, 94, 125-132. DOI:10.1016/j.colsurfb.2012.01.048

21. R. R. Karri, J. N. Sahu, N. S. Jayakumar, J. Taiwan. Inst. Chem. Eng, 2017, 80, 472-487. DOI:10.1016/j.jtice.2017.08.004

22. R. R. Karri, N. S. Jayakumar, J. N. Sahu, J. Mol. Liq, 2017, 231, 249-262. DOI:10.1016/j.molliq.2017.02.003

23. L. P. Lingamdinne, J. R. Koduru, R. K. Jyothi, Y. Y. Chang, J. K. Yang, Desalin. Water. Treat. 2016, 57, 13066-13080. DOI:10.1080/19443994.2015.1055813

24. H. Roh, M. R. Yu, K. Yakkala, J. R. Koduru, J. K. Yang, Y. Y. Chang, J. Ind. Eng. Chem, 2015, 26, 226-233.

DOI:10.1016/j.jiec.2014.11.034

25. G. Vazquez, J. Gonzalez-Alvarez, S. Freire, M. Lopez-Lorenzo, G. Antorrena, Bioresour. Technol. 2002, 82, 247-251.

DOI:10.1016/S0960-8524(01)00186-9

26. G. Vazquez, J. Gonzalez-Alvarez, A. I. Garcia, M. S. Freire, G. Antorrena, Bioresour. Technol. 2007, 98, 1535-1540. DOI:10.1016/j.biortech.2006.06.024

27. S. K. Nadavala, H. Che Man, H. S. Woo, BioResources. 2014, 9, 5155-5174. DOI:10.15376/biores.9.3.5155-5174

28. Z. Aksu, J. Yener, Waste Management. 2001, 21, 695-702. DOI:10.1016/S0956-053X(01)00006-X

29. O. Hamdaoui, E. Naffrechoux, J. Hazard. Mater. 2007, 147, 381-394. DOI:10.1016/j.jhazmat.2007.01.021

30. S. Liu, J. Pan, J. Cao, X. Dai, M. Meng, R. Wu, J. Yao, Y. Yan, Chem. Eng. J. 2016, 284, 10-20.

DOI:10.1016/j.cej.2015.08.133

31. J. Pan, J. Luo, J. Cao, J. Liu, W. Huang, W. Zhang, L. Yang, RSC Advances. 2016, 6, 93894-93904. DOI:10.1039/C6RA20919J

32. M. Radhika, K. Palanivelu, J. Hazard. Mater. 2006, 138, 116124. DOI:10.1016/j.jhazmat.2006.05.045

33. I. A. W. Tan, A. L. Ahmad, B. H. Hameed, J. Hazard. Mater. 2009, 164, 473-482. DOI:10.1016/j.jhazmat.2008.08.025 
34. B. H. Hameed, I. A. W. Tan, A. L. Ahmad, Chem. Eng. J. 2008 , 144, 235-244. DOI:10.1016/j.cej.2008.01.028

35. G. Chen, Y. Wang, Z. Pei, Environ. Sci. Pollut. Res. 2014, 21, 2002-2008. DOI:10.1007/s11356-013-2122-y

36. D. Zhang, G. Zhao, J. Yu, T. Yan, M. Zhu, F. Jiao, J. Wuhan Univ. Technol. Mater. Sci. Ed. 2016, 31, 1211-1218.

37. A. Denizli, N. Cihangir, N. Tuzmen, G. Alsancak, Bioresour Technol. 2005, 96, 59-62.

DOI:10.1016/j.biortech.2003.11.029

38. S. Y. Lagergren, Zur Theorie der sogenannten Adsorption geloster Stoffe. 1898.

39. Y. S. Ho, G. McKay, Process Biochemistry. 1999, 34, 451-465. DOI:10.1016/S0032-9592(98)00112-5

40. M. Suguna, N. S. Kumar, V. Sreenivasulu, A. Krishnaiah, Sep. Sci. Technol. 2014, 49, 1613-1622.

DOI:10.1080/01496395.2014.901361

41. W. J. Weber, J. C. Morris, J. Sanitary Eng. Div. 1963, 89, 31-60.
42. I. Langmuir, J. American Chem. Soc. 1916, 38, 2221-2295. DOI:10.1021/ja02268a002

43. N. Siva Kumar, A. Subba Reddy, V. M. Boddu, A. Krishnaiah, Toxicol. Environ. Chem. 2009, 91, 1035-1054.

DOI:10.1080/02772240802541338

44. A. Moghal, K. Reddy, S. Abu Sayeed Mohammed, M. Ali Al-Shamrani, W. Zahid, J. Testing Evaluation. 2017, 45, 1-15. DOI:10.1520/JTE20160066

45. M. Dubinin, L. Radushkevich, Proceedings Academy of Sciences Physics Chemistry Section. USSR. 1947, 55, 331-333, 875890.

46. J. Fan, J. Zhang, C. Zhang, L. Ren, Q. Shi, Desalination, 2011, 267, 139-146. DOI:10.1016/j.desal.2010.09.016

47. P. Ojha, S. Rathilal, K. Singh, South African J. Chem. Eng. 2014, 19, 1-21.

48. I. A. W. Tan, A. L. Ahmad, B. H. Hameed, J. Hazard. Mater. 2008, 153, 709-717. DOI:10.1016/j.jhazmat.2007.09.014

\section{Povzetek}

Večina industrijskih odpadkov je onesnaženih s strupenimi in težko razgradljivimi fenolnimi spojinami. Te predstavljajo glavni vir vodnega onesnaženja, zato je pri čiščenju takšnih industrijskih odpadnih voda poglavitnega pomena razvoj cenovno učinkovitih postopkov. $\mathrm{V}$ tem delu je raziskana učinkovitost predhodno neobdelanega prahu borovega lubja (PBP) kot poceni bioadsorbenta za odstranjevanje 2,4,6 triklorofenola (2,4,6-TCP) iz vodnega medija. Rezultati šaržnih raziskav so bili obdelani z znanimi ravnotežnimi modeli, od katerih je Freundlihova izoterma najbolje opisala raziskovano biosorpcijo. Pri $25 \pm 1^{\circ} \mathrm{C}$ je znašala maksimalna biosorpcijska kapaciteta $\left(q_{\max }\right) 289,09 \mathrm{mg} / \mathrm{g}$, kar je višje od vrednosti za večino bioadsorbentov podanih v literaturi. Odstranjenega je bilo kar 97\% 2,4,6-TCP, biosorpcija pa je bila hitra, saj je bilo ravnotežje doseženo v 120 minutah. Elovičev model dobro opiše kinetične podatke. Na osnovi visoke biosorpcijske kapacitete in hitrega odstranjevanja se PBP lahko uporabi za učinkovit in poceni postopek čiščenja odpadne vode, kontaminirane z 2,4,6-TCP. 